\title{
Assessment of Cracks on a Building at Tarkwa in Ghana with Respect to Foliations and Joints in Foundation Tarkwaian Rocks
}

\author{
Tetteh G. M. ${ }^{{ }^{*}}$, Mensah F. A. ${ }^{2}$ \\ ${ }^{1}$ University of Mines and Technology, P.O. Box 237, Tarkwa. Ghana \\ ${ }^{2}$ Building and Road Research Institute, CSIR, Kumasi, Ghana \\ "gmtetteh@umat.edu.gh
}

\begin{abstract}
Buildings constructed with bricks develop cracks and other structural damages after minor foundation displacements or settling from loading. The defects are formed because foundation rock quality deteriorates due to inherent discontinuities such as faults, joints and weathering which reduce the bearing capacity of the foundation rocks and soils. These can affect the structural integrity of the building resulting in cracks or collapse of the building. This paper highlights cracks on the building which was previously used by Ghana National Fire Service at Tarkwa, in the Western Region of Ghana in 2007 before it was pulled down for a new structure to be built. The investigations on the cracks involved taking strike, dip and dip directions, length, and extent of separation. These data were compared with measurements of foliations and joints on Tarkwaian conglomerate and quartzite outcrops close to the area. The study revealed that the cracks on the building were almost horizontal with some vertical deviations. The cracks generally strike northwest, almost perpendicular to the strike direction of the foliations and joints in the Tarkwaian rocks which mostly strike south-south west. The major crack separations were extensive along directions of SSW (65-92mm), NW (70mm), E (42mm) and NE $(25 \mathrm{~mm})$. These suggest that the building was settling in a major direction parallel to the general strike of the major joints and foliations and along their main dip direction. Visual examination of cracks indicated that, a few of the cracks might have been accentuated by ground vibrations from the heavy trucks on the nearby major road.
\end{abstract}

Keywords: cracks on building, orientations, joints, foliations, foundation, Tarkwaian rocks, Ghana

\section{INTRODUCTION}

Common problems in many masonry structures which mostly arise after construction relate to cracks on walls. This defect may not be structurally significant, but is often aesthetically unacceptable and repaired at considerable cost. Cracks can result from external forces; shrinking and swelling of some clay when subjected to moisture variations, differential foundation movements, and settling from dimensional changes in the masonry work. Cracks on buildings can also be caused by expansion and shrinkage due to clay content in foundation soils due to poor compaction of foundations. Bricks made of concrete are prone to alkali-aggregate deterioration as alkali in cement combine with hydroxyl ions which react with some types of aggregates within the concrete to form micro-cracks that allow water to penetrate the concrete and accelerate the severity of damage, though this defect may normally take about 5 to 10 years to manifest (Anon., 2011).

Site investigations may look beyond soils to the underlying rocks as physical structures in areas with known potential hazards may not be able to withstand load or stress. Some buildings, such as those made of bricks are exceedingly brittle and may sustain cracks and other structural damage following foundation rock displacements. Horizontal cracks near the bottom of walls result from a great load or 
pressure put on the foundation or wall (Anon., 2011). In the foundation rocks are structures which include joints. Joints are fractures in a rock along which no appreciable displacement occurs and may be barren of infillings (Hobbs et al., 1976).

This study was conducted in January, 2007 on the old Ghana National Fire Service building near the Tarkwa Railway Station before it was pulled down to reconstruct a new structure. The work was intended to come out with factors leading to development of cracks in the building. It involved identification, classification and orientation of cracks which were plotted on rose diagrams and compared with foliation and joint orientations in nearby Tarkwaian conglomerate outcrops.

\subsection{Geological Setting}

The Tarkwaian rocks in the Ashanti belt of Ghana stretch from near Axim in the Western Region to the edge of the Voltaian basin near Agogo in the Ashanti Akim District (Kesse, 1985).

The Birimian consists of metamorphosed volcanic rocks and metasedimentary rocks. Initial subdivision by Junner (1935, 1940) placed the rocks into Lower Birimian made up of metasedimentary rocks while the Upper Birimian mainly comprises of metavolcanic rocks. Leube et al. (1990) indicated that these rocks are contemporaneous and form a lateral facies. Granitoids referred to as belt granitoids intruded into the volcanic rocks whilst basin granitoids intruded into the metasedimentary rocks. The Tarkwaian is regarded as younger than the Birimian as the basal rock of the Tarkwaian which is the Kawere conglomerate, which consists of reworked pebbles from the Birimian, is made up of sub-rounded closely packed pebbles of Birimian metavolcanic, metasedimentary rocks and granitoids, carbonates, quartz and other veins minerals and rocks. A palaeoplacer gold bearing banket quartz conglomerate overlies this polymictic Kawere conglomerate. The Tarkwaian stratigraphy by Junner (1942) from the youngest above is as follows:

- Huni Sandstone and Dompim Phyllites

- Tarkwa Phyllites

- Banket Series

- Kawere Conglomerate

The Banket Series is subdivided into footwall and hanging wall quartzites separated by a sequence of mineralised quartz-pebble conglomerates and pebbly quartzites. The pebbles show that the fluvial deposition was from east and north-east. The Tarkwaian sequence has been subjected to low-grade regional metamorphism of greenschist facies. According to Allibone et al. (2002), the Tarkwaian has been subjected to five episodes of deformation accompanied by thrust faults and dolerite sills.

\section{METHODS USED}

The buildings which use to house the Ghana National Fire Service station at Tarkwa was selected for the study based on its conspicuous structural defects and its proximity to a market, taxi station and a filling station and so posed a threat to public safety.

The building was a low-rise building with about six offices and toilet facilities. It was situated ninetytwo meters $(92 \mathrm{~m})$ north of an old mining shaft into an underground mining crosscut. The building was constructed with sand mixed with cement (sandcrete). The joints in the building were described with respect to orientation, length and extent of opening by using a measuring tape. Orientation of cracks were plotted on a rose diagram. The foundation rocks which outcrop behind this structure and in the neighbourhood are the Tarkwaian conglomerate and quartzite of which the strike and dip directions were plotted and compared with the cracks in the building. 


\section{RESULTS}

The cracks identified on the walls which did not show any displacement between the horizontal and the vertical were described as syn-horizontal and vertical cracks (Fig. 1A). The horizontal crack on the southern part of the building might have widened up to about four times its width (Fig. 1B). Diagonal cracks were common and were probably stopped and later reactivated or offset by vertical cracks (Figs. 2A and 2B). At a corner of the wall, occurred a vertical crack which might have changed into horizontal cracks in the wall (Fig. 3A). Peeling was more extensive in diagonal and horizontal cracks which were wavy (Figs. 2A and 3C). Thus three generations of repeated or reactivated cracks occurred in the walls - the first had extensive widths with significant peeling (Figs 1-3); second generation cracks had limited opening (Figs 4A and 4B); whilst the latest had narrow widths (Figs. 5A and5B).
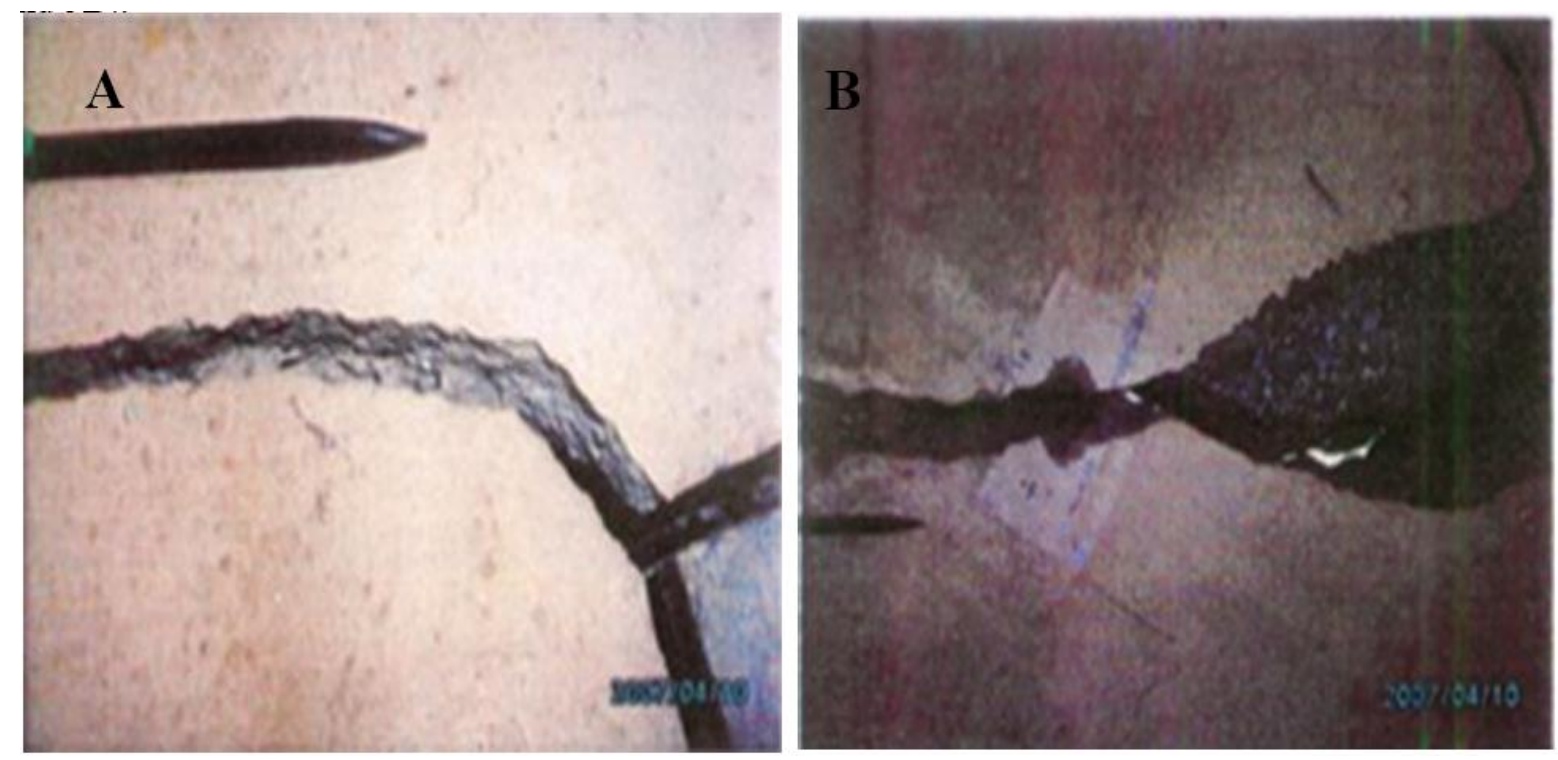

Figure1. Photographs of horizontal cracks on walls showing a) syn-horizontal and vertical crack relationship and $\boldsymbol{b})$ widened crack.
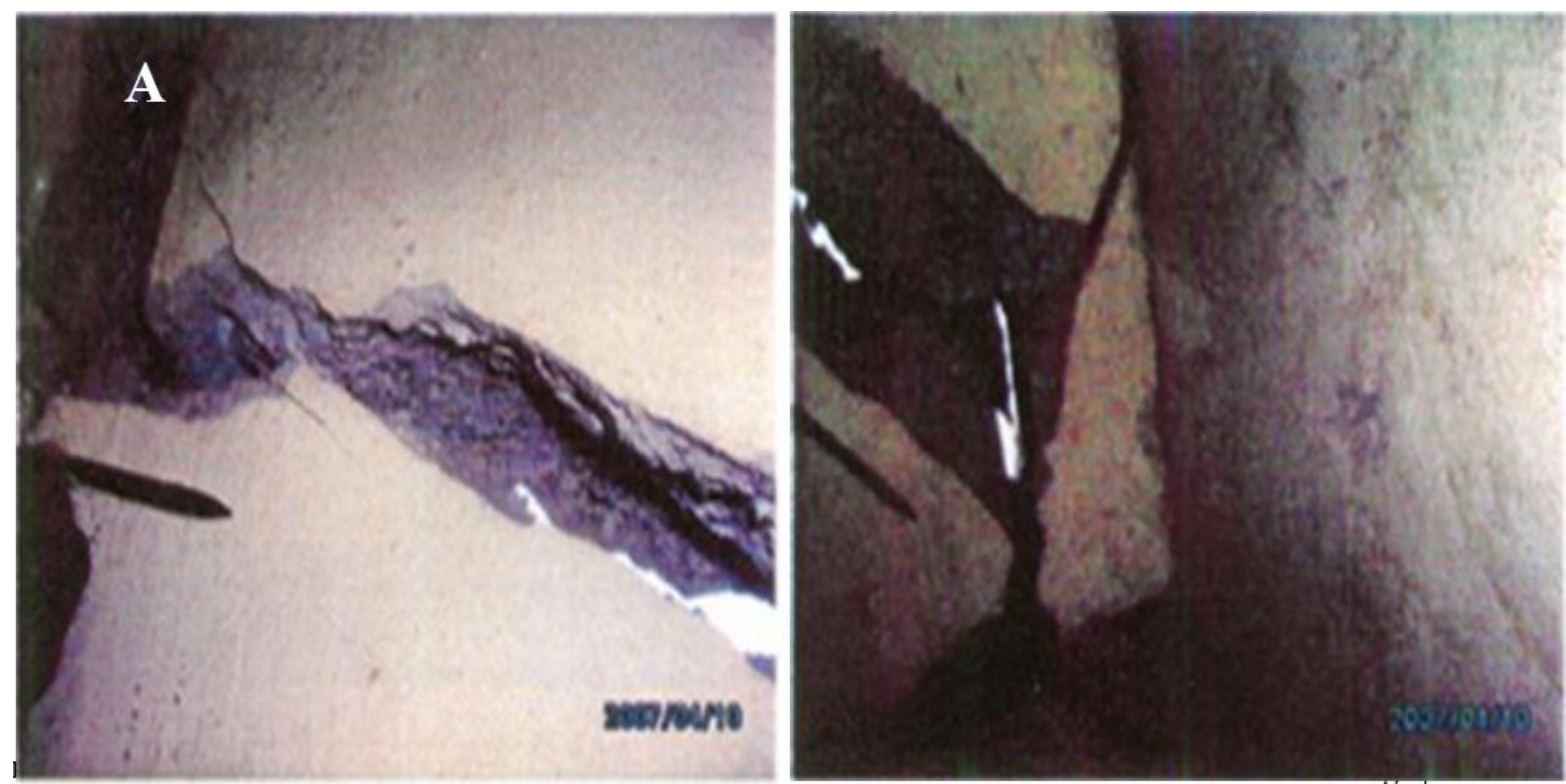

Figure2. Photographs of Diagonal Cracks showing a) Reactivation by later crack and b) Offset by Vertical Crack 
Tetteh G. M. \& Mensah F. A.
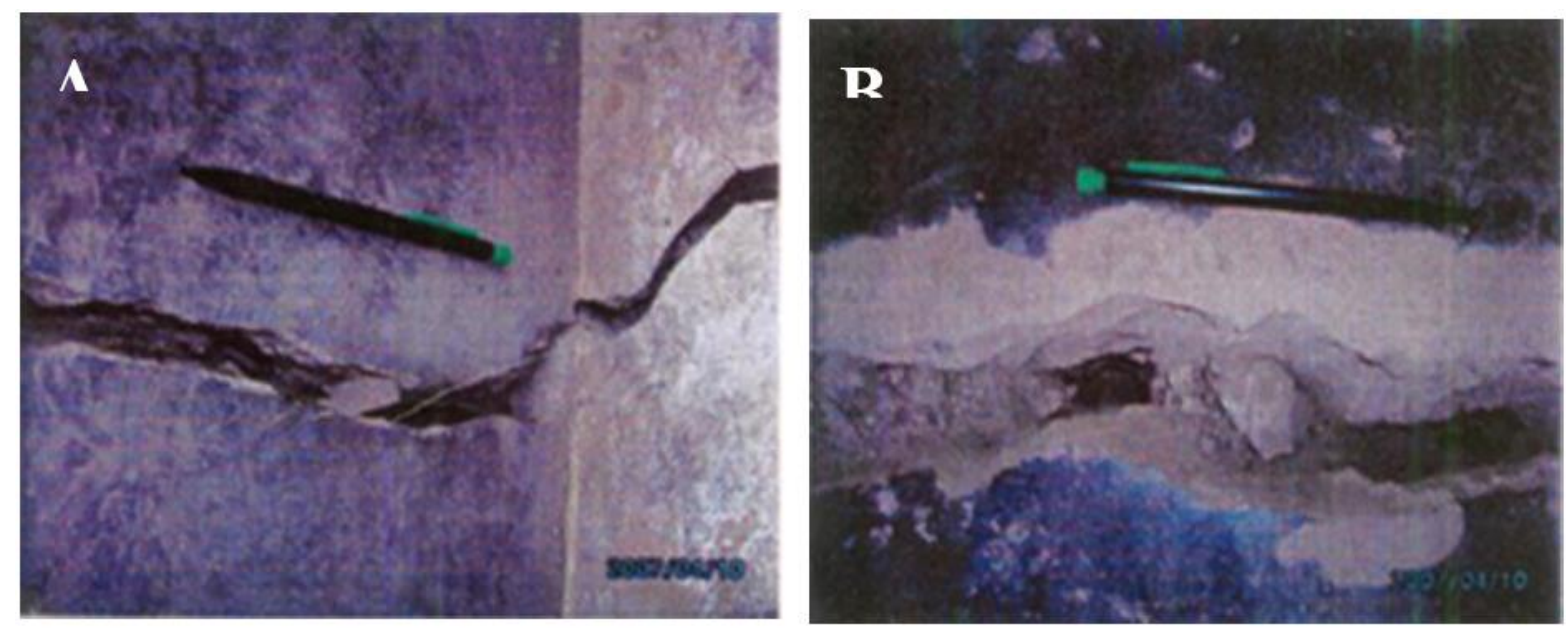

Figure3. Photographs of Cracks on the floor at the southern part of the Building showing a) Horizontal crack in the east developed into Diagonal Crack at the west b) Horizontal crack
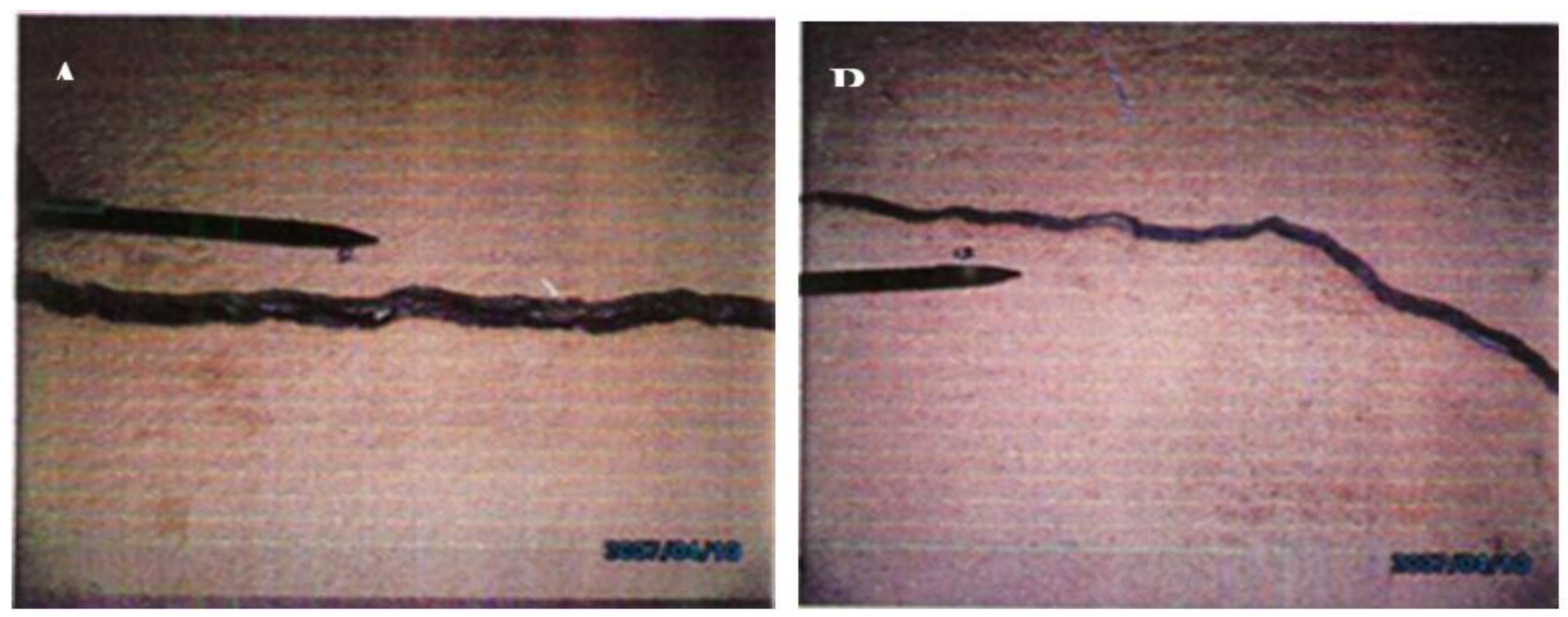

Figure4. Photographs of Second Generation Cracks on Walls with limited opening showing a) Wavy Horizontal Crack and b) Wavy Horizontal Crack migrating into Diagonal Crack
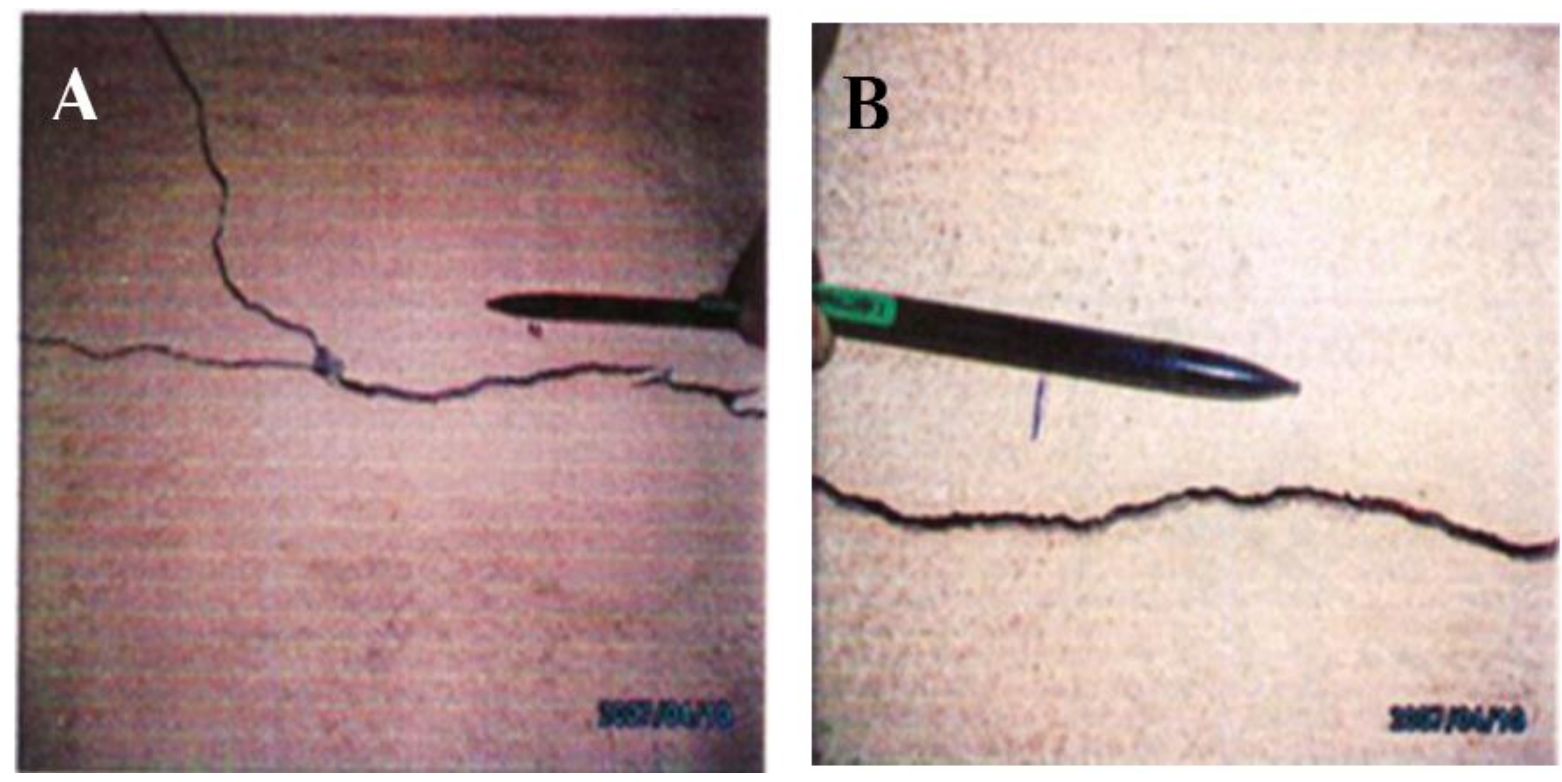

Figure5. Photographs of Cracks on the western part of the Building showing a) Vertical Crack taken over by a Horizontal Crack b) Wavy Horizontal Crack 
Assessment of Cracks on a Building at Tarkwa in Ghana with Respect to Foliations and Joints in Foundation Tarkwaian Rocks

Table1. Description of Cracks developed on the Building

\begin{tabular}{|c|c|c|c|c|c|}
\hline $\begin{array}{c}\text { Crack } \\
\text { Location }\end{array}$ & $\begin{array}{c}\text { Length of } \\
\text { Crack } \\
(\boldsymbol{m})\end{array}$ & $\begin{array}{c}\text { Crack } \\
\text { Separation } \\
(\boldsymbol{m m})\end{array}$ & Strike & Dip Direction & State of Crack \\
\hline Wall & 2.4 & 11 & 330 & 70 & Stable \\
\hline Wall & 1.8 & 24 & 330 & 40 & Stable \\
\hline Wall & 1.5 & 10 & 330 & 50 & Stable \\
\hline Wall & 0.15 & & 320 & 70 & Stable \\
\hline Wall & 0.9 & 42 & 110 & 30 & Unstable \\
\hline Wall Corner & 0.15 & 3 & 320 & 50 & Unstable \\
\hline Wall & 0.6 & 5 & 130 & 32 & Unstable \\
\hline Wall & 0.6 & 4 & 80 & 50 & Stable \\
\hline Wall & 1.0 & 13 & 80 & 50 & Unstable \\
\hline Wall & 0.8 & 8 & 270 & 50 & Unstable \\
\hline Wall & 0.6 & 65 & 220 & 150 & Stable \\
\hline Wall & 0.6 & 70 & 320 & 300 & Unstable \\
\hline Wall & 0.7 & 92 & 230 & 330 & Unstable \\
\hline Floor & 2.1 & 25 & 40 & 140 & \\
\hline
\end{tabular}

The cracks occur mainly on the walls and less often at the corners and had lengths ranging from 0.15 to $2.4 \mathrm{~mm}$. Crack separations vary from $3 \mathrm{~mm}$ to $92 \mathrm{~mm}$. Cracks with separation above $25 \mathrm{~mm}$ were described as unstable with those less that $25 \mathrm{~mm}$ considered as generally stable. An exception to this rule was a crack at the corner wall with minimal separation (Table 1). Rose diagram of cracks were plotted (Fig. 7).

Measurement of foliations and joints in the Tarkwaian conglomerate and quartzite in the neighbourhood of the building is shown in Table 2. From the table, foliations generally strike between 210 to 230 degrees and dip from 30 to 58 degrees (Table 2). Joints strike in three main directions (190 - 200, 150, and 340 - 345 degrees) and dip gently - moderately. Rose diagrams of foliations and joints were plotted to highlight these orientations (Fig. 8).

Table2. Attitute of Foliations and Joints in Tarkwaian Outcrop near the Building

\begin{tabular}{|c|c|c|c|}
\hline \multirow{2}{*}{ Structure } & Strike & Dip Amount & Dip Direction \\
\cline { 2 - 4 } & $($ degree $)$ & $($ degree $)$ & 320 \\
\hline & 230 & 50 & 300 \\
\hline & 220 & 46 & 310 \\
\hline \multirow{3}{*}{ Foliation } & 230 & 38 & 300 \\
& 216 & 50 & 300 \\
\cline { 2 - 4 } & 220 & 50 & 310 \\
\hline & 228 & 58 & 310 \\
\hline & 230 & 48 & 312 \\
\hline & 210 & 30 & 230 \\
\hline \multirow{2}{*}{ Joint } & 150 & 48 & 292 \\
\hline & 200 & 60 & 300 \\
\hline & 200 & 50 & 80 \\
\hline & 345 & 84 & 140 \\
\hline & 340 & 70 & 310 \\
\hline
\end{tabular}




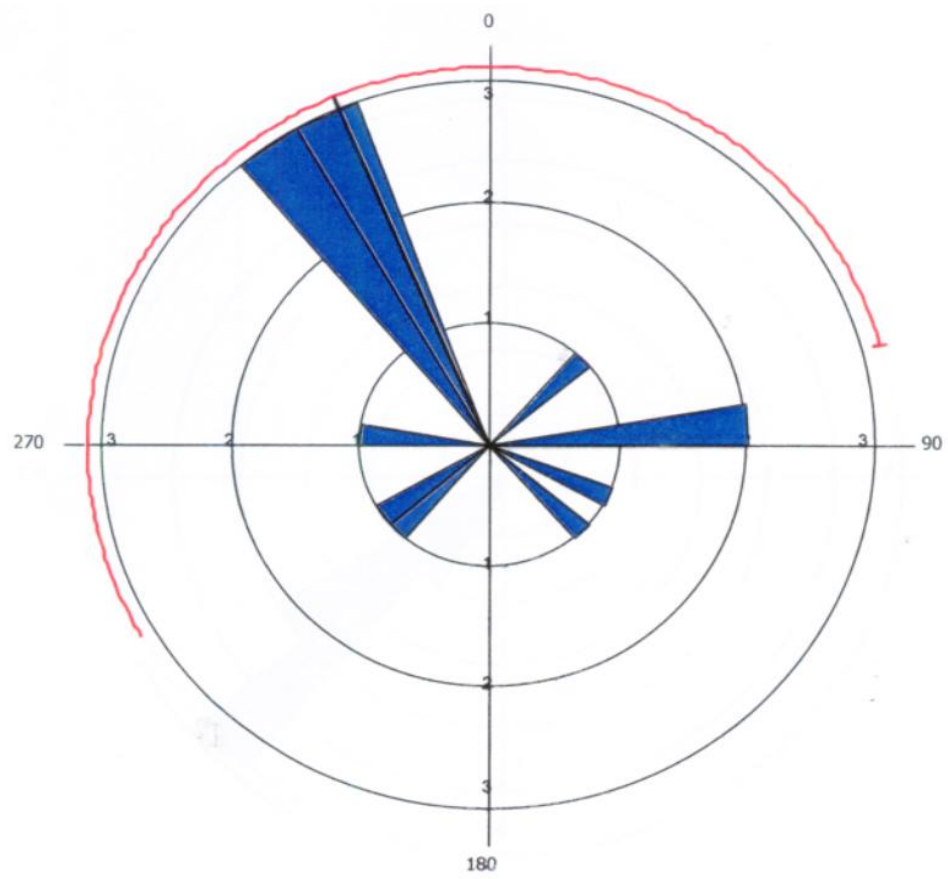

Figure6. Rose Diagram of Cracks on the Ghana National Fire Service Building showing main NW and minor E directions $(N=14)$.
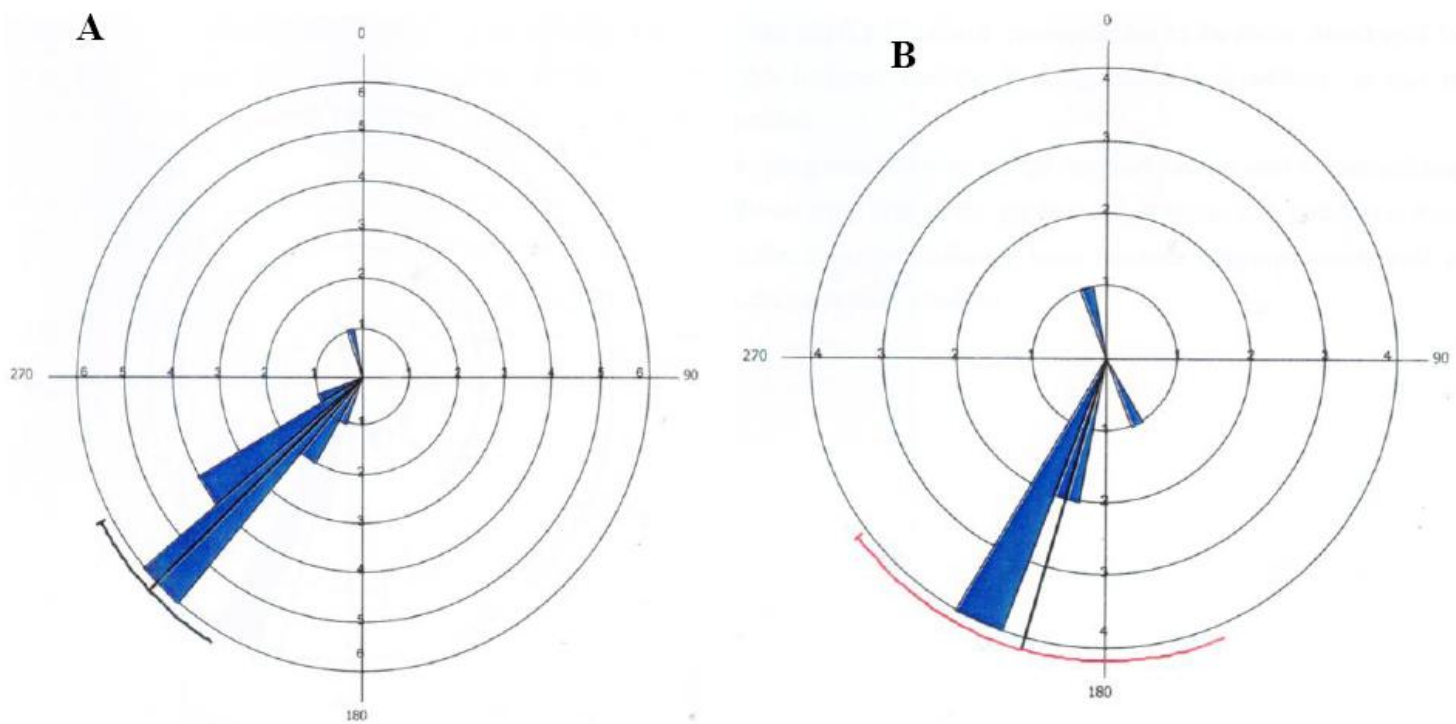

Figure7. Rose Diagram of structural measurements in the Metaconglomerate/Quartzite at the Mining Pit and Outcrop showing A) Foliations strike mainly in $S W$ direction $(N=15)$ B) Joints strike mainly in SSW direction $(N=8)$.

\section{DisCUSSION}

The old Ghana National Fire Service building at Tarkwa before it was pulled down was situated on the Tarkwaian conglomerate which is the auriferous rock mined at Tarkwa. The location of the building was close to an abandoned underground mine shaft which intersects a cross-cut trending about NNESSW.

Strike directions of the cracks on the building, however were mainly to northwest with minority to the east (Fig. 7). Most of the cracks were horizontal to nearly horizontal with vertical displacement near the bottom of the wall. According to Anon. (2011) these types of cracks resulted from great load or 
pressure that was placed on the foundation beyond the bearing capacity to cause settling of the structure. Cracks on the building strike in a direction different from the joints and foliations in the immediate foundation rocks. Foliations and joints in the outcrops close to the underground mine strike mainly in south-southwest direction and dip moderately at about 50 degrees (Table 2, Figs. 8A and 8B).

Possible causes for strike directions of the cracks which were at right angles to the major direction of the foliations and joints might have emanated from previous mining of the conglomerate in a direction usually subparallel to the strike of foliations and bedding. Hence the maximum stress direction on the rocks coincided with the minimum stress direction on the building. This was plausible as the building probably was settling under its maximum load to cause extensive cracks, to offset the stress along the main strike directions of the cracks.

The major crack separations (widths) were according to strike directions of cracks which were SSW $(65-92 \mathrm{~mm}), \mathrm{NW}(70 \mathrm{~mm}), \mathrm{E}(42 \mathrm{~mm})$ and NE $(25 \mathrm{~mm})$. These directions suggest that crack separations were most pronounced for cracks parallel to general strike of foliations which are parallel to an underground cross-cut in the rock, second by strike of cracks perpendicular to the cross-cut and less by cracks which corresponded to general direction of dip of foliation. The latest might be due to possible slip by adjustment of the rocks toward the mine openings.

\section{Conclusions}

The old Ghana National Fire Service building at Tarkwa before it was pulled down had its foundation on the Tarkwaian conglomerate which is the auriferous rock mined at Tarkwa in the Western Region of Ghana.

Cracks on the building were mostly horizontal to nearly horizontal with some vertical displacements near the bottom of the walls. These cracks strike mainly northwest whereas the joints and foliations in the immediate foundation rock strike generally to the south-southwest.

The major crack separations (widths) reduce according to directions from SSW, NW, E and NE. These width variations conform to general strike of foliations, trend of an underground mining cross-cut in the rock, and general direction of dip of foliation which could serve as direction of slip should there be an adjustment of the rocks toward the mine opening.

These findings probably show that the building was settling under its maximum load leading to development of extensive cracks to offset the stress along the main strike directions in the rocks.

\section{REFERENCES}

Allibone, A., Teasdale, J., Cameron, G., Etheridge, M., Uttley, P., Soboh, A., Appiah-Kubi, J., Adanu,A., Arthur, R., Mamphey, J., Odoom, B., Zuta, J., Tsikata, A., Pataye, F., Famiyeh, S. \& Lamb, E. (2002). Timing and structural controls on gold mineralisation at the Bogoso Gold Mine, West Africa. Economic Geology, 17, 949-969

Anon. (2011) Typical Foundation Problems. Available: http://www.stonehengefoundations.com (May 22, 2011). [Accessed: $5^{\text {th }}$ June 2015 at 19.24]

Hobbs, B. E., Means, W. D. \& Williams, P. F. (1976). An Outline of Structural Geology. John Wiley and Sons, New York, 1-571

Junner, N. R. (1940). The Geology of the Gold Coast and Western Togoland, Gold Coast Geological Survey, Bulletin 11, 1-40 
Tetteh G. M. \& Mensah F. A.

Junner, H. R., Hirst, T. \& Service, H. (1942). The Tarkwa Goldfield. Gold Coast Geological Survey, Memoir, 6, 1-75

Junner, N. R. (1935), Gold in the Gold Coast, Gold Coast Geological Survey, Accra (Reprinted 1973), 4, 1-67

Kesse, G. O. (1985). The Mineral and Rock Resources of Ghana, A. A. Balkema, Rotterdam, 1-610

Leube, A., Hirdes, W., Mauer, R. \& Kesse, G. O. (1990). The Early Proterozoic Birimian Supergroup of Ghana and its associated gold mineralisation, Precambrian Research, 46, 139-165 